CLINICAL STUDY

\title{
A novel mutation of the KAL1 gene in monozygotic twins with Kallmann syndrome
}

\author{
Takeshi Matsuo ${ }^{1}$, Shingo Okamoto ${ }^{1}$, Yukiko Izumi ${ }^{2}$, Akiko Hosokawa ${ }^{3}$, Takashi Takegawa ${ }^{1}$, Hiroshi Fukui ${ }^{1}$, \\ Zaw $\operatorname{Tun}^{4}$, Katsuya Honda ${ }^{4}$, Ryoji Matoba ${ }^{4}$, Ke-ita Tatsumi ${ }^{2}$ and Nobuyuki Amino ${ }^{2}$ \\ ${ }^{1}$ Third Department of Internal Medicine, Nara Medical University, 840 Shijo-cho, Kashihara, Nara 634-8522, Japan, ${ }^{2}$ Department of \\ Laboratory Medicine, Osaka University Graduate School of Medicine D2, 2-2 Yamadaoka, Suita, Osaka 565-0871, Japan, ${ }^{3}$ Hikari Clinic, \\ 1-8-8 Gakuen-kita, Nara 631-0036, Japan and ${ }^{4}$ Department of Legal Medicine, Osaka University Graduate School of Medicine F3, 2-2 Yamadaoka, \\ Suita, Osaka 565-0871, Japan \\ (Correspondence should be addressed to Y Izumi; Email: yizumi@labo.med.osaka-u.ac.jp)
}

\begin{abstract}
Objective: Kallmann syndrome is defined by the association of hypogonadotropic hypogonadism and anosmia. The KAL1 gene is responsible for the X-linked form of Kallmann syndrome. In this study we describe monozygotic twins with Kallmann syndrome due to the same mutation in the KAL1 gene.

Design: We studied male monozygotic twins with Kallmann syndrome.

Methods: We analyzed the KAL1 gene using the PCR-direct sequencing method. The twins' mother was examined for the identified mutation.

Results: We identified a 14 bp deletion from codon 419 in exon 9 (Pro419del14) in both KAL1 genes of the twins. This was a novel mutation in the KAL1 gene and was responsible for Kallmann syndrome. As Pro419del14 was not detected in the mother of the twins, Pro419del14 was a germline mutation originating from them. These monozygotic twins showed different LH and FSH responses to LH-RH stimulation and different phenotypes such as complications, physiques and psychiatric characters.

Conclusions: We report an identical KAL1 gene mutation in the monozygotic twins with Kallmann syndrome. As these monozygotic twins showed different phenotypes in some respects, we suggest that factors other than mutations in the KAL1gene affect the symptomatic features of Kallmann syndrome.
\end{abstract}

European Journal of Endocrinology 143 783-787

\section{Introduction}

Kallmann syndrome is defined by the association of hypogonadotropic hypogonadism and anosmia. Familial cases are transmitted as X-linked, autosomal recessive or autosomal dominant traits, but sporadic cases have also been reported. The KAL1 gene, a candidate gene for X-linked Kallmann syndrome, was cloned in 1991 by Ballabio et al. (1) and Legouis et al. (2). This gene consists of 14 exons spanning approximately $210 \mathrm{~kb}$ on $\mathrm{Xp} 22.3(3,4)$. The KAL1 gene probably encodes a protein functioning in neuronal migration and axonal targeting $(1,2)$. Numerous KAL1 gene mutations responsible for Kallmann syndrome have been reported in X-linked families and sporadic cases (5-16). We describe here the first reported case of monozygotic twins with Kallmann syndrome, and show that they had a novel KAL1 gene abnormality.

\section{Case report}

Two 19-year-old men (Cases 1 and 2) were admitted to our hospital for delay of puberty. They were twins. At birth Case 1 was $49.5 \mathrm{~cm}$ long and weighed $3100 \mathrm{~g}$, while Case 2 was $44.0 \mathrm{~cm}$ long and weighed $1990 \mathrm{~g}$. Case 2 was diagnosed as having a mild ventricular septal defect. Both grew normally but Case 1 was always taller and heavier than Case 2 (Fig. 1). Their parents had noticed since their infancy that they could not recognize any smells. Even at 16 years old, they had no pubertal development. On physical examination, Case 1 was obese; he was $181 \mathrm{~cm}$ tall and weighed $100 \mathrm{~kg}$. His penis was $4.8 \mathrm{~cm}$ in length, and his testes were both $2 \mathrm{ml}$ in volume. Smell tests disclosed severe hyposmia. He also had exotropia. Case 2 was $173 \mathrm{~cm}$ tall and weighed $76 \mathrm{~kg}$. His penis was $4.2 \mathrm{~cm}$ in length, and his testes were both $1 \mathrm{ml}$ in volume. Smell tests disclosed severe 


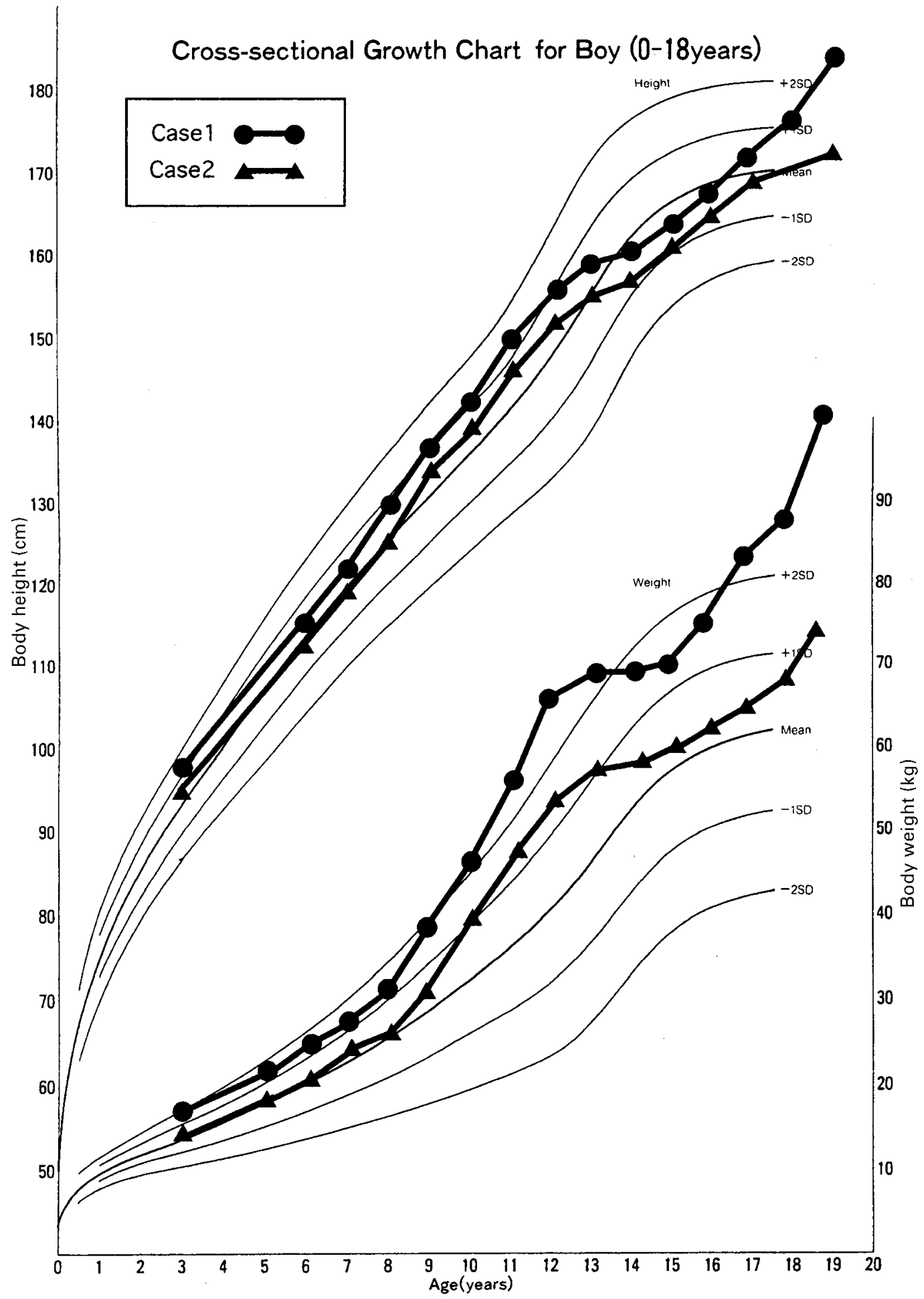

Figure 1 Growth curves. Case 1 was always taller and heavier than Case 2.

hyposmia, as for Case 1. Congenital hyposmia and hypogonadism were not found among their relatives.

The basal FSH, LH and testosterone levels of Cases 1 and 2 were all below adult reference values, as shown in Table 1. Their serial LH-RH provocation tests showed stepwise LH and FSH elevations. On the seventh day, both $\mathrm{LH}$ and $\mathrm{FSH}$ responded normally and the peak values for Case 2 were higher than those 

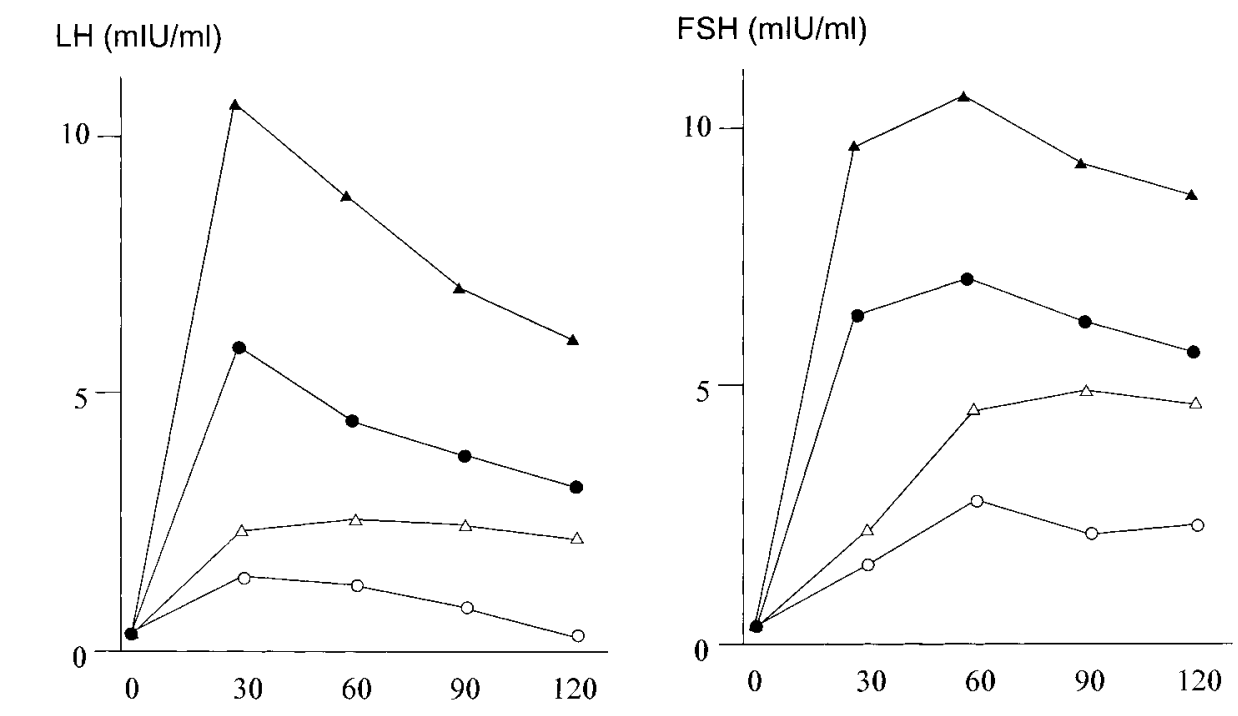

Case1:the first day $(\circlearrowleft-0)$ Case1:the seventh day $(\bullet \rightarrow) \quad$ Case2:the first day $(\Delta-\Delta)$ Case2:the seventh day $(\bullet \bullet)$

Figure 2 Serial LH-RH provocation tests (200 $\mu \mathrm{g} /$ day i.m. for 7 days). On the seventh day, both LH and FSH responded normally, and the peak values for Case 2 were higher than those for Case 1.

for Case 1 (Fig. 2). Clomiphene citrate provocation tests showed neither $\mathrm{LH}$ nor FSH response in either case. Evaluation of the other pituitary hormones showed normal basal levels (Table 1). These findings were consistent with hypogonadotropic hypogonadism with hyposmia, and these twins were diagnosed with Kallmann syndrome. Abdominal ultrasound examination showed no renal abnormality in either case.

As eight kinds of human leukocyte antigen (HLA) type analysis showed A24(9), A26(10), B7, B60(40), Cw7, Cw3, DR1 and DR11(5) in both cases and the twins had a common placenta at birth, they were considered to be monozygotic twins. Confirmation of twin monozygosity was obtained by analysis of DNA polymorphisms. The zygosity analysis gave a probability of monozygosity of $99.999 \%$. Psychologically, the

Table 1 Basal levels of pituitary and sex hormones in Cases 1 and 2. Values in parentheses indicate reference range and units.

\begin{tabular}{lcc}
\hline & Case 1 & Case 2 \\
\hline GH $(<0.5 \mathrm{ng} / \mathrm{ml})$ & 0.1 & 0.2 \\
Sm.C $(259-351 \mathrm{ng} / \mathrm{ml})$ & 442 & 415 \\
TSH $(0.24-3.7 \mu \mathrm{Ul} / \mathrm{ml}$ & 2.0 & 1.4 \\
T3 $(0.7-2.1 \mathrm{ng} / \mathrm{ml})$ & 1.2 & 1.4 \\
T4 $(4.5-12.3 \mu \mathrm{g} / \mathrm{dl})$ & 7.4 & 8.1 \\
LH $(1.8-5.2 \mathrm{mlU} / \mathrm{ml})$ & $<0.5$ & $<0.5$ \\
FSH $(2.9-8.2 \mathrm{mlU} / \mathrm{ml})$ & $<0.5$ & $<0.5$ \\
Testosterone $(2.7-10.7 \mathrm{ng} / \mathrm{ml})$ & 0.4 & 0.3 \\
E $_{2}(15-60 \mathrm{pg} / \mathrm{ml})$ & 21 & 20 \\
\hline
\end{tabular}

Yatabe-Guilford personality test (17) showed that Case 1 was an extrovert and Case 2 was an introvert.

\section{Methods}

\section{Endocrinological studies}

Serum LH, FSH, GH, somatomedin C (Sm.C), TSH and estradiol $\left(\mathrm{E}_{2}\right)$ were measured by solid phase immunoradiometric assays using the SPAC-S LH, SPAC-S FSH (Daiichi RI, Tokyo, Japan), GH 'Daiichi’ (Daiichi RI, Tokyo, Japan), somatomedin C·II 'Ciba Corning' (Ciba Corning Diagnostic, Tokyo, Japan), TSH·RIABEAD II (Dainabot, Tokyo, Japan) and estradiol ${ }^{125}$ I (CIS Diagnostic, Tokyo, Japan) kits, respectively. Testosterone, tri-iodothyronine (T3) and thyroxine (T4) were measured by radioimmunoassays using the DPC total testosterone (DPC, Tokyo, Japan), T-3 RIABEAD II (Dainabot) and T-4 RIAKIT II (Dainabot) kits, respectively.

Serial LH-RH provocation tests The serum LH and FSH responses to $\mathrm{LH}-\mathrm{RH}(200 \mu \mathrm{g}$ /day i.m. for 7 days $)$ were determined every $30 \mathrm{~min}$ for $2 \mathrm{~h}$ on the first and the seventh days.

Clomiphene citrate provocation tests Clomiphene citrate (100 mg/day for 7 days) was administered, and serum LH and FSH were measured before and after stimulation. 


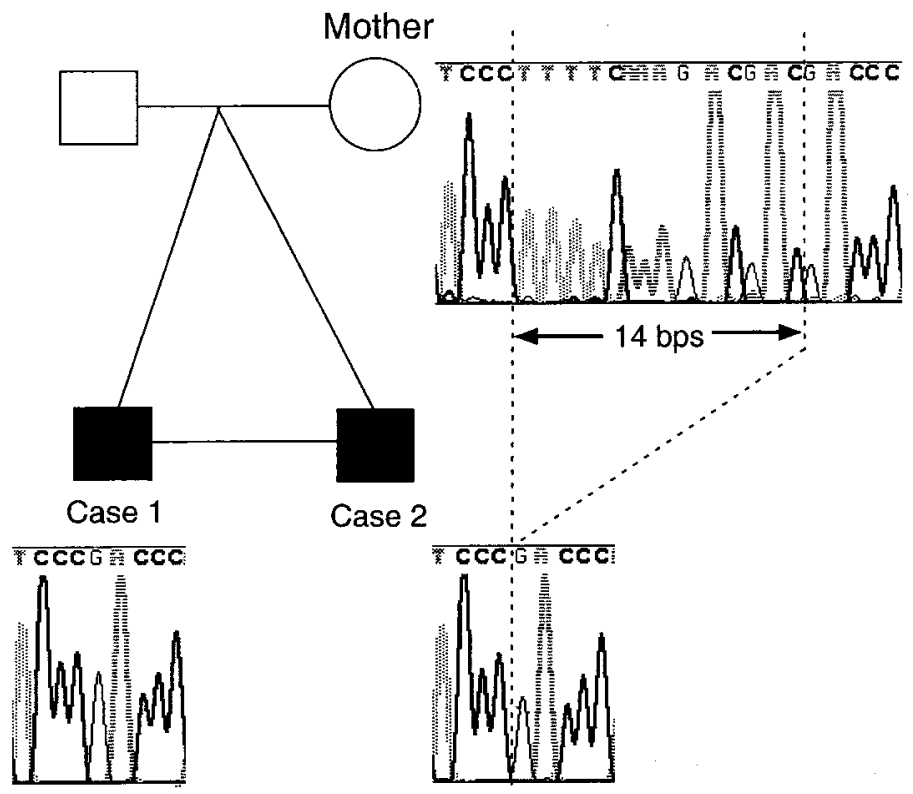

Figure 3 Sequence analysis of exon 9 in the $K A L 1$ gene. The mutation in the twins was a 14 bp deletion starting at codon 419 in exon 9. This mutation was not detected in their mother.

\section{DNA extraction, PCR and sequencing}

Genomic DNA was extracted from peripheral leukocytes using a simple salting out method (18). All 14 exons of the KAL1 gene were amplified by PCR as previously reported (16) using primers described by Hardelin et al. (8). The PCR-amplified fragments were purified and submitted to a sequencing reaction using the ABI PRISM dye terminator cycle sequencing ready reaction kit with AmpliTaq DNA polymerase, FS (Perkin-Elmer, Applied Biosystems Division, Foster City, CA, USA). For all 14 exons, both DNA strands were sequenced using an ABI PRISM 310 genetic analyzer (Perkin-Elmer).

\section{HLA type analysis}

HLA-A, -B, -C and -DR loci were analyzed using the Terasaki-NIH standard method.

\section{Analysis of DNA polymorphisms}

DNA polymorphisms were analyzed by the use of two variable numbers of tandem repeats (ApoB, MCT118) and seven short tandem repeats (TPOX, vWA31, TH01, FES/FPS, HPRTB, ARA, STR X1).

\section{Results}

In both KAL1 genes of the twins the same novel mutation was found, namely, a 14 bp deletion starting at codon 419 in exon 9 (Pro419del14) (Fig. 3). Pro419del14 resulted in frameshift and truncation of the KAL1 protein due to a premature stop codon at codon 440. Pro419del14 was not detected in the KAL1 gene on both $\mathrm{X}$ chromosomes of the twins' mother.

\section{Discussion}

Here we reported monozygotic twins with Kallmann syndrome due to a 14 bp deletion in exon 9 starting at codon 419 in the KAL1 gene. As Pro419del14 results in frameshift and truncation of the KAL1 protein due to a premature stop codon at codon 440 , the third and fourth fibronectin type III-like repeats of the KAL1 protein, a domain involved in the processes of neuronal migration and axonal targeting, are lost $(1,2)$ and so this mutation is considered to be responsible for Kallmann syndrome.

This is the first report on monozygotic twins with an identical KAL1 gene mutation. Interestingly, these monozygotic twins, possessing the same genotype, showed different phenotypes in some respects. First, although the serial LH-RH provocation tests showed stepwise LH and FSH elevations, the response in Case 2 was higher than that in Case 1. Secondly, Case 1 had exotropia, while Case 2 had a ventricular septal defect. Although Kallmann syndrome patients with congenital heart diseases were reported previously, every patient lacked family history and their KAL1 genes were not analyzed (19). Exotropia had never been reported as complications of Kallmann syndrome with KAL1 gene mutations. Therefore these abnormalities are thought to be caused by factors other than Pro419del14. Thirdly, Case 1 was taller and heavier than Case 2. Finally, the Yatabe-Guilford personality test showed that Case 1 was an extrovert and Case 2 was an introvert. The presence of these symptomatic heterogeneities in Kallmann syndrome with the same mutation in the KAL1 gene suggests the existence of other factors that modulate the function of the KAL1 gene, except for the other genes. Some previous studies reported identical twins with Kallmann syndrome with 
discordant phenotypes, but their KAL1 genes were not analyzed $(20,21)$. Further, in another family with Xlinked Kallmann syndrome with identical partial deletion in the KAL1 gene, intrafamilial variability was reported. In that family, one of three affected brothers had mild hyposmia and showed normal pubertal progression (11).

Since Pro419del14 was not detected in the twins' mother, we considered that Pro419del14 is a germline mutation originating from the twins. Because all mutations we have found occurred in either probands or the mother (16), and only one large pedigree with the KAL1 gene mutation has been reported (12), we suggest that mutation in the KAL1 gene may only rarely be inherited because of the associated male infertility.

In conclusion, here we have reported monozygotic twins with Kallmann syndrome due to a novel $14 \mathrm{bp}$ deletion in exon 9 starting at codon 419 in the KAL1 gene. Different phenotypes in the twins suggest that other factors might also be important for development of clinical characteristics.

\section{Acknowledgements}

This work was supported in part by grants from the Ministry of Education, Science and Culture, the Ministry of Health and Welfare of Japan.

\section{References}

1 Ballabio F, Guioli S, Pragliola A, Incerti B, Bardoni B \& Tonlorenzi $\mathrm{R}$ et al. A gene deleted in Kallmann's syndrome shares homology with neural cell adhesion and axonal pathfinding molecules. Nature 1991353 529-536.

2 Legouis R, Hardelin JP, Levilliers J, Claverie JM, Compain S \& Wunderle $\mathrm{V}$ et al. The candidate gene for the X-linked Kallmann syndrome encodes a protein related to adhesion molecules. Cell $199167423-435$.

3 Incerti B, Guioli S, Pragliola A, Zanaria E, Borsani G \& Tonlorenzi R et al. Kallmann syndrome gene on the $\mathrm{X}$ and $\mathrm{Y}$ chromosomes: implications for evolutionary divergence of human sex chromosomes. Nature Genetics 19922 311-314.

4 del Castillo I, Cohen-Salmon M, Blanchard S, Lutfalla G \& Petit C. Structure of the X-linked Kallmann syndrome gene and its homologous pseudogene on the Y chromosome. Nature Genetics 19922 305-310.

5 Bick D, Franco B, Sherins RJ, Heye B, Pike L \& Crawford J et al. Intragenic deletion of the KALIG-1 gene in Kallmann's syndrome. New England Journal of Medicine 1992326 1752-1755.

6 Guioli S, Incerti B, Zanaria E, Bardoni B, Franco B \& Taylor K et al. Kallmann syndrome due to a translocation resulting in an X/ Y fusion gene. Nature Genetics 19921 337-340.
7 Hardelin JP, Levilliers J, Young J, Pholsena M, Legouis R \& Kirk J et al. Xp22.3 deletions in isolated familial Kallmann's syndrome. Journal of Clinical Endocrinology and Metabolism 1993 76 827-831.

8 Hardelin JP, Levilliers J, Blanchard S, Carel JC, Leutenegger M \& Pinard-Bertelletto JP et al. Heterogeneity in the mutations responsible for $\mathrm{X}$ chromosome-linked Kallmann syndrome. Human Molecular Genetics 19932 373-377.

9 Quinton R, Duke VM, de Zoysa PA, Platts AD, Valentine A \& Kendall B et al. The neuroradiology of Kallmann's syndrome: a genotypic and phenotypic analysis. Journal of Clinical Endocrinology and Metabolism 199681 3010-3017.

10 Georgopoulos NA, Pralong FP, Seidman CE, Seidman JG, Crowley WF Jr. \& Vallejo M. Genetic heterogeneity evidenced by low incidence of KAL-1 gene mutations in sporadic cases of gonadotropin-releasing hormone deficiency. Journal of Clinical Endocrinology and Metabolism 199782 213-217.

11 Parenti G, Rizzolo MG, Ghezzi M, Di Maio S, Sperandeo MP \& Incerti B et al. Variable penetrance of hypogonadism in a sibship with Kallmann syndrome due to a deletion of the KAL gene. American Journal of Medical Genetics 199557 476-478.

$12 \mathrm{Gu}$ WX, Colquhoun-Kerr JS, Kopp P, Bode HH \& Jameson JL. A novel aminoterminal mutation in the KAL-1 gene in a large pedigree with X-linked Kallmann syndrome. Molecular Genetics and Metabolism 199865 59-61.

13 Maya-Nuñez G, Zenteno JC, Ulloa-aguirre A, Kofman-Alfaro S \& Mendez JP. A recurrent missense mutation in the KAL gene in patients with X-linked Kallmann's syndrome. Journal of Clinical Endocrinology and Metabolism $1998 \mathbf{8 3}$ 1650-1653.

14 Maya-Nuñez G, Cuevas-Covarrubias S, Zenteno JC, UlloaAguirre A, Kofman-Alfaro S \& Méndez JP. Contiguous gene syndrome due to deletion of the first three exons of the Kallmann gene and complete deletion of the steroid sulphatase gene. Clinical Endocrinology $1998 \mathbf{4 8} 713-718$.

15 O’Neill MJ, Tridjaja B, Smith MJ, Bell KM, Warne GL \& Sinclair AH. Familial Kallmann syndrome: a novel splice acceptor mutation in the KAL gene. Human Mutation 199811 340-342.

16 Izumi Y, Tatsumi K, Okamoto S, Hosokawa A, Ueno S \& Fukui $\mathrm{H}$ et al. A novel mutation of the KAL1 gene in Kallmann syndrome. Endocrine Journal 199946 651-658.

17 Guilford JP \& Martin HG. In Personnel Inventory. Beverly Hills, California: Sheridan Supply Co, 1943.

18 Miller SA, Dykes DD \& Polesky HF. A simple salting out procedure for extracting DNA from human nucleated cells. Nucleic Acids Research 1988161215.

19 Cortez AB, Galindo A, Arensman FW \& Van Dop C. Congenital heart disease associated with Kallmann syndrome. American Journal of Medical Genetics $1993 \mathbf{4 6}$ 551-554.

20 Hermanussen M \& Sippell WG. Heterogeneity of Kallmann's syndrome. Clinical Genetics 198528 106-111.

21 Hipkin LJ, Casson IF \& Davis JC. Identical twins discordant for Kallmann's syndrome. Journal of Medical Genetics 199027198 199.

Received 16 May 2000

Accepted 24 August 2000 